\title{
WZÓR OBYWATELA
}

\author{
Jacek Kurczewski
}

Uniwersytet Warszawski

Studia socjologiczne rozpocząłem w 1965 roku. Dość szybko spotkałem się z Kuba. Było to spotkanie bardzo charakterystyczne dla typu roli, jaką Kuba spełniał w środowisku akademickim. Dziesięć lat temu wspominałem w „Zeszytach Literackich” operację dydaktyczną, którą na mnie Kuba, jako starszy kolega, wykonał. Mianowicie pomagał mi bardzo intensywnie, trzy dni i trzy noce, pracować nad pewnym tekstem o dialektyce, po czym na końcu sam zrozumiałem, że to sensu nie ma, a Kuba dobrotliwie to zaakceptował.

Drugi aspekt dla mnie ważny muszę wyjaśnić. Proszę pamiętać, że totalitaryzm totalitaryzmem, ale były daty. I są pewne różnice już wewnątrz totalitaryzmu, które są bardzo istotne. Spór o to, kiedy było więcej, a kiedy mniej wolności, ma sens, bo inaczej się żyło i inne były nastroje społeczne. Historia warszawskiej socjologii przywróconej w 1957 roku ma swój okres pierwszy, który się kończy wraz z tym, co dla mnie jest końcem Instytutu Socjologii, socjologii na Traugutta, a ten koniec to Marzec 1968 roku. W budynku na Traugutta, na pierwszym chyba piętrze jest długi korytarz. Na końcu korytarza, na prawo był pokój Ossowskiego i jego Zakładu, a później Stefana Nowaka. Na lewo był drugi pokój, pokój Ossowskiej i jej Zakładu czy Katedry, w którym ja miałem szczęście akurat pracować, a Kuba bywał w tym drugim pokoju. Odbudowana socjologia była jednym z niewielu konkretnych osiagnięć Października 1956 roku. To było coś bardzo szczególnego. Byłem pierwszym rocznikiem, który został przyjęty na studia $z$ takiego normalnego, regularnego naboru. Przedtem było to bardzo szczególne środowisko. Dużo arystokratów i artystek, dużo... No, w ogóle pięknie było. Mało może porządnie... Pili wszyscy, bawili się, dyskutowali. Czytano. Byłem z ostatniego pokolenia, które dostało jednocześnie cała twórczość Steinbecka, prawie cała twórczość Amerykanów, bo Hemingway był wydany jeszcze w czterdziestym którymś roku. Egzy- 
stencjalizm, jazz, surrealizm. To wszystko wybuchło i było zupełnie inne jakby pokolenie młodzieży polskiej. Socjologia stanowiła też wyrwę w tym dotychczasowym nudnym, socjalistycznym totalitaryzmie. Obok zreszta właśnie jazzu i innych miłych rzeczy. Kolorowych skarpetek i pończoch. I to mniej więcej trwało tak do Marca.

Atmosfera się psuła z roku na rok, było coraz gorzej, ale kiedy się wchodziło na studia, tak jak ja, to najpierw człowiek się gubił w tej wolności. Ale po chwili pojawiał się Kuba, który reprezentował starszy rocznik i zarząd czegoś, co mało atrakcyjnie teraz brzmi: Koło Naukowe Studentów Socjologii. Była to bardzo świadomie prowadzona „robota polityczna”. Polegała na tym, że starsi studenci rozglądali się wśród pierwszoroczniaków, przyglądali się, oceniali i rozpoczynali pracę indywidualną. Ustrój miał od początku w Kubie zdecydowanego i świadomego wroga, który właśnie prowadził z innymi swoimi kolegami tę pracę. Polegała przede wszystkim na pokazaniu dobra i zła oraz wyraźnych kryteriów. W tamtych czasach kryterium nie było podejrzenie o współpracę z UB, choć takie rzeczy ciagle funkcjonowały, bo zawsze kogoś podejrzewano na roku. To była jawna rzecz, mianowicie przynależność do PZPR. Socjologowie dzielili się na tych, którzy do Partii należą, i tych, którzy do Partii nie należą. Ossowski, Ossowska to były te dwie wyspy bezpartyjne, które były obudowane, i ja byłem starannie przez Kube już na tym pierwszym roku pouczony. Nie wymienię nazwiska pewnego socjologa, Kuba mnie zaprowadził do biblioteki Ossowskiego w tamtym pokoju, pokazał mi, że profesor trzyma tam jego książkę z dedykacją, bo do domu jej nie wziął. Natomiast z kolei był profesor, i jego nazwisko powiem, Jerzy Wiatr, którego książek nigdy się nie brało. Od razu mnie pouczył, że z Wiatrem się nie rozmawia, że w ogóle nie jest to człowiek, który w środowisku socjologicznym jest do zaakceptowania, bo totalnie zakłamany i produkujący pseudobadania nad pseudowyborami.

Przychodzi Marzec. Oczywiście, sa rozmaite wydarzenia, które go poprzedzają. Następuje zmiana tonu, robi się coraz brutalniej. Nie ukrywam, że byłem przeciwnikiem wiecu na placu przed rektoratem na Uniwersytecie Warszawskim. Jeszcze w przeddzień nie pamiętam, czy rano, co już by w ogóle było absurdalne, usiłowałem przekonać Kubę, że wiec należy odwołać. Bo to nie było tak, że nikt nie przewidywał, co będzie. Było wiadomo, że ryzyko interwencji milicyjnej, jak myśmy mówili „prowokacji”, będzie duże. Mnie się wydawało, że jest to ryzyko groźne. No, co się stało, to się stało. Nie mam zamiaru mówić, że byłem jakimś prorokiem. Ale straty były duże, choć uważam po latach, że dobrze się stało, że miało miejsce 
wystąpienie młodzieży studenckiej. Niezależnie od tego, że indywidualnie łamało ono losy.

Skutki Marca były poważne dla socjologii instytucjonalnej. Szybko nastąiło de facto rozwiązanie Wydziału. Został on na nowo powołany i konstruowany. Dopiero wówczas następuje drugi okres historii socjologii, z przymusowo egzekwowanym szkoleniem marksistowskim. To jest już inny okres, na którego tle z kolei rok 1980 to znowuż jest wyzwoleniem. I proszę pamiętać, że z naszej perspektywy, uczestników tej skomplikowanej historii, tak to wygląda.

Kim był Kuba? Mówimy, że był wirtuozem. Rzeczywiście wirtuozem, w sensie „virtu obywatelskiej”, która praktykował i nad którą się zastanawiał. Jest książeczka Ossowskiej, oklepana można powiedzieć, ale która zawsze, uważam, powinna być w tym kraju znana na pamięć: Wৃór obywatela w ustroju demokratycznym. Jakie cechy powinien posiadać dobry obywatel? Tych cech jest tam trzynaście. Trzynaście, może feralnie, dlatego że nikt nie jest w stanie zapamiętać trzynastu cech. Ale w skrócie mówiąc, jeżeli usłyszycie, że coś nie pasuje do Kuby, to proszę podnieść rękę. Aspiracje perfekcjonistyczne, otwartość umysłu, dyscyplina wewnętrzna, tolerancja, aktywność, odwaga cywilna, uczciwość intelektualna, krytycyzm, odpowiedzialność za słowo, uspołecznienie, rycerskość, wrażliwość estetyczna i poczucie humoru. To jest przecież Kuba. Kuba zrealizował podręcznik demokratycznego obywatela Marii Ossowskiej, naszej wspólnej nauczycielki. Chciałbym jeszcze przytoczyć fragment z tekstu Ossowskiej; uważam, że o tym trzeba pamiętać.

Presja pewnych wzorów uwydatnia się jaskrawo w tak zwanym brązownictwie. Jest to proces retuszowania jakiejś postaci, zwykle zmarłej, ale czasem jeszcze żyjącej tak, by postać tę dociągnąć do wzoru cieszącego się naszym szacunkiem. Oto w biografii wielkiego uczonego zaciera się starannie ślad jego miłostek. Najwidoczniej w mniemaniu brązownika tylko pewien typ życia erotycznego przystoi uczonemu. Ktoś inny w biografii męża stanu ukrywa jego odstępstwa od kościoła. Oto siostra jednego ze znanych poetów francuskich poddaje po jego śmierci starannej cenzurze jego listy.

Wiadomości o niezliczonych fałszerstwach, jakich się ludzie dopuszczali, by dociagnnąc kogoś do jakiegoś wzoru, sa niezmiernie pouczające dla badacza wzorów osobowych. Myślę, że przez pamięć i szacunek dla Kuby musimy dbać, żebyśmy w brązownictwo nie popadli. Niepunktualność była 
oczywiście karygodną wadą Kuby, którąjuz dziesięć lat temu wypomniałem, ale z czułością o tej niepunktualności pamiętam. Są inne, ale na pewno nie było wśród nich wady nietolerancji. Kuba mówił, m.in. przekazał mi taką maksymę: „Profesor może mówić wszystko”. Wybaczcie! 